\title{
Biological Conversion from Slaughter Blood into Amino Acid Liquefied Fertilizer
}

\author{
Y. W. Jeon, H. J. Kim, Y. H. Cho, and H. M. Yoo
}

\begin{abstract}
The traditional way for treatment of slaughter blood is just to decompose the powdered blood into peptide or amino acid chemically using phosphoric acid or hydrochloric acid. In order to get the powdered blood, dewatering and drying processes are required, which are causing wastewater, odor, and cost problems. The objectives of this research were to convert raw slaughter blood to amino acid liquefied fertilizer biologically, by the processes of crushing and enzymatic (protease) decomposition. It is concluded that to maximize the efficiency of enzymatic decomposition for raw slaughter blood, the optimum operation conditions are determined that the enzyme reaction time is $\mathbf{1 0} \mathbf{~ h r s , ~ t h e ~ e n z y m e ~ m i x i n g ~ r a t i o ~ i s ~} 0.5$ $w / w \%$, and the enzyme reaction temperature is $40{ }^{\circ} \mathrm{C}$. Decomposed blood by crushing and enzymatic reaction showed decrease of total protein concentration from $32.9 \mathrm{mg} / \mathrm{mL}$ to 1.5 $\mathrm{mg} / \mathrm{mL}$, and average particle size from $46.92 \mu \mathrm{m}$ to $19.89 \mu \mathrm{m} .3$ ) Through gel filtration chromatography (GFC) analysis, decomposed proteins were converted mostly into small-sized protein and peptide (<13 $\mathrm{kDa})$ not into amino acid level.
\end{abstract}

Index Terms-Slaughter blood, amino acid liquefied fertilizer, enzymatic decomposition, protease

\section{INTRODUCTION}

As of 2011, there are daily production of 890.4 tons and annual production of 213,697 tons of slaughter blood at a total of 147 slaughterhouses in South Korea [1]. The number of slaughtered animals and the consequent amount of slaughter blood are increasing annually in a direct relation to the increase in national income. Excluding the slaughter blood that is sold as food products, most of the blood waste is disposed in the ocean. However, with the significant reinforcement of the standards for marine waste disposal, which includes slaughter blood, in accordance with the Marine Pollution Prevention Act and Enforcement Regulations that were amended according to the '96 Protocol,' marine waste disposal is expected to be gradually prohibited in phases until absolute prohibition in February 2012. At present, the cost to dispose slaughter blood in the ocean varies depending on the distance between the disposal site and the slaughterhouse, but the average cost is approximately 80 dollars per ton. Thus, considering the annual production of slaughter blood, the annual cost of marine waste disposal reaches up to nearly 10 million dollars.

Slaughter blood consists of plasma and blood cell. Plasma

Manuscript received March 31, 2013; revised May 25, 2013. This research was supported by "Korea Institute of Planning and Evaluation for Technology in Food, Agriculture, Forestry and Fisheries (IPET)" (project 112040-3).

All the authors are with Green Environmental Industry Division, Korea Testing Laboratory, Seoul, 152-718, Republic of Korea (e-mail: ywjeon@gmail.com). and blood cell are useful protein containing albumin, globulin, fibrinogen and hemoglobin. Thus, protein separated from slaughter blood is used in various fields including food, animal feed, fertilizers, laboratory, pharmaceutics, industry, etc [2].

In the past, most of the slaughter blood, considered as animal waste, produced in mass at slaughterhouses (cattle, pigs, etc.) was collected in a hygienic method to be used as an ingredient feed to increase the nutritious value of animal feed. However, after the outbreak of mad cow disease (bovine spongiform encephalopathy, BSE) in the late 90s, addition of slaughter blood to herbivorous ruminant livestock feed became strictly prohibited and instead, it became developed as high quality agricultural fertilizer.

In Korea, several experiments using slaughter blood were already tried. Chang et al. [3] has studied the production of angiotensin I converting enzyme inhibitory peptides from bovine blood plasma protein and the results showed the possibility for the industrial production of antihypertensive peptides from slaughter blood plasma proteins. Ma et al. [4] was investigated the utilization of porcine blood in yeast culture for animal diets and effects of yeast culture on the growth of broiler chicks. In addition, development of new adhesives and the production of probiotics as a feed additive using blood of slaughtered animal(Ministry of Agriculture and Forestry) have been researched in 1990s [5]-[6].

However, slaughter blood is mostly dried before being packaged and distributed as powdered blood, which is produced by dewatering slaughter blood through heating, clotting and compressing before it is dried and crushed. Abundant in nitrogen, powdered blood is widely used as a liquefied fertilizer to improve the soil of environmentally-friendly farms. However, production of powdered blood consists of dewatering and drying processes, which are expensive and generate wastewater and odor [7].

This study attempted to produce amino acid liquefied fertilizer from slaughter blood through crushing and enzymatic decomposition processes. Amino acids have great effects on plants. Studies that investigated the effects of amino acid fertilizer on grass growth and soil quality reported findings that there was an increase of $70.6 \sim 90.1 \%$ in the nitrogen utilization rate in the area treated with amino acid fertilizer compared to the control group. Compared to the control group, the nitrogen, magnesium and chlorophyll contents of grass in the area treated with amino acid fertilizer showed a $22 \sim 23 \%, 13 \%, 22 \sim 39 \%$ increase, respectively, with an approximately $12 \%$ increase of the total grass weight on a dry basis. This led to the conclusion that amino acid fertilizer stimulates grass growth and increases the nitrogen utilization rate in the soil, which also facilitates grass growth [8]. 
TABLE I: CurRent Status of Slaughter and Production of Slaughter Blood In Korea

\begin{tabular}{|l|l|l|l|l|l|}
\hline Classification & $\begin{array}{l}\text { Slaughter house } \\
\text { (places) }\end{array}$ & $\begin{array}{l}\text { Number of slaughter } \\
\text { (ea/year) }\end{array}$ & $\begin{array}{l}\text { Number of slaughter } \\
\text { (ea/day) }\end{array}$ & $\begin{array}{l}\text { Blood } \\
\text { (ton/year) }\end{array}$ \\
\hline Cattle & 93 & 769,432 & 3,206 & 6,155 \\
\cline { 1 - 5 } Pig & $13,805,582$ & 57,523 & 34,514 \\
\hline Chicken & 41 & $626,481,504$ & $2,610,340$ & 75,177 \\
\hline Duck & 13 & $48,414,285$ & 201,726 & 9,682 & 143.8 \\
\hline Sum & 147 & $689,470,803$ & $2,872,795$ & 313.2 \\
\hline
\end{tabular}

Note) Data obtained from National Veterinary Research and Quarantine Service (2008)

\section{MATERIALS AND METHOD}

\section{A. Preparation of Raw Slaughter Blood Samples}

Blood from slaughter pigs was used in this experiment; the slaughter blood was collected in a hygienic manner at a pig slaughterhouse situated in Gyeonggi-do, Korea, immediately after slaughter and was transported to the lab in a refrigerated vehicle. The characteristics of the blood from slaughter pigs used in the experiment are shown in Table II. The results of the 3-components analysis showed that the blood was composed of $77.27 \%$ moisture, $20.89 \%$ combustible component content and 1.84\% non-combustible component content. For chemical characteristics of the blood on a dry basis, $\mathrm{C}, \mathrm{H}, \mathrm{O}, \mathrm{N}, \mathrm{S}$, and $\mathrm{Cl}$ were $49.30 \%, 7.23 \%, 23.01 \%$, $14.81 \%, 0.17 \%$, and $1.07 \%$, respectively. The slaughter blood used in this experiment was discovered to be an excellent fertilizing ingredient from its $\mathrm{C} / \mathrm{N}$ ratio, an important factor in the fertilizer production process, which was found to be 6.21. Although the nitrogen content was found to be higher than that of other organic wastes, there were concerns of nitrogen loss through emission as ammonia gas, which is also the cause of odor. Thus, during the conversion of the blood proteins into amino acids through biological enzymatic decomposition, it is important to prevent the loss of the nitrogen content as ammonia gas. Heavy metals, including lead, cadmium, copper and chromium, etc., were detected in trace amount, which were satisfying 'fertilizer legal standards' of Korea. Also, the $\mathrm{pH}$ was determined to be 6.51 , while the salinity was determined to be $0.46 \%$.

TABLE II: CHARACTERISTICS OF THE SLAUGHTER BLOOD USED IN THIS EXPERIMENT

\begin{tabular}{|c|c|c|c|}
\hline \multicolumn{2}{|c|}{ Items } & Unit & Concentration \\
\hline \multirow{3}{*}{ 3-components } & Moisture & $\mathrm{wt} \%$ & 77.27 \\
\hline & Combustible & $\mathrm{wt} \%$ & 20.89 \\
\hline & Non-combustible & $\mathrm{wt} \%$ & 1.84 \\
\hline \multirow{6}{*}{$\begin{array}{c}\text { Chemical } \\
\text { characteristics(d.b.) }\end{array}$} & Carbon & $\mathrm{wt} \%$ & 49.30 \\
\hline & Hydrogen & $\mathrm{wt} \%$ & 7.23 \\
\hline & Oxygen & $\mathrm{wt} \%$ & 23.01 \\
\hline & Nitrogen & $\mathrm{wt} \%$ & 14.81 \\
\hline & Sulfur & $\mathrm{wt} \%$ & 0.17 \\
\hline & Chlorine & $\mathrm{wt} \%$ & 1.07 \\
\hline \multirow{6}{*}{ Heavy metals(d.b.) } & As & $\mathrm{mg} / \mathrm{kg}$ & N.D. \\
\hline & $\mathrm{Pb}$ & $\mathrm{mg} / \mathrm{kg}$ & 0.25 \\
\hline & $\mathrm{Cd}$ & $\mathrm{mg} / \mathrm{kg}$ & 0.25 \\
\hline & $\mathrm{Cu}$ & $\mathrm{mg} / \mathrm{kg}$ & 1.65 \\
\hline & $\mathrm{Hg}$ & $\mathrm{mg} / \mathrm{kg}$ & N.D. \\
\hline & $\mathrm{Cr}$ & $\mathrm{mg} / \mathrm{kg}$ & 0.12 \\
\hline \multicolumn{2}{|c|}{$\mathrm{pH}$} & - & 6.51 \\
\hline \multicolumn{2}{|c|}{$\mathrm{C} / \mathrm{N}$ ratio } & - & 6.21 \\
\hline \multicolumn{2}{|c|}{ Salinity } & $\%$ & 0.46 \\
\hline
\end{tabular}

Note) d.b.: dry basis, N.D.: not detectable

\section{B. Production of Liquefied Fertilizer from Slaughter Blood}

The slaughter blood transported to the lab underwent the processes shown in Fig. 1. The prepared slaughter blood underwent a three-step process (crushing, enzymatic decomposition and filtration/mixing) to investigate its potential for conversion into amino acid liquefied fertilizer. Insufficient crushing of blood causes incomplete decomposition of proteins, which can cause gas emission and odor. A crushing device with applications of the hammer mill and knife \& impeller methods was developed to crush the slaughter blood as part of a pre-treatment process conducted prior to the enzymatic decomposition. After, enzymatic biodegradation and fermentation were attempted under various conditions. The enzyme used in this study was an industrial protease produced by D company, and this industrial enzyme is part of the serine protease and metallo protease lines with a microbial origin. Potassium sorbate was added as a preservative to inhibit decomposition and fermentation during the post-treatment process after enzymatic decomposition. The decomposed blood was then filtered through a sieve for analysis. The experiment was conducted with a pilot-scaled batch type reactor which was $1,000 \mathrm{~kg} /$ one batch capacity. In order to determine the optimum reaction conditions, the experiment was carried out multiple times while varying the enzymatic decomposition time between 4 and $14 \mathrm{hrs}$. Also, the enzyme mixing ratio and reaction temperature were also varied during the experiment. The reaction temperature was adjusted by the reactor enclosed in an external water jacket to control the water temperature inside the jacket.

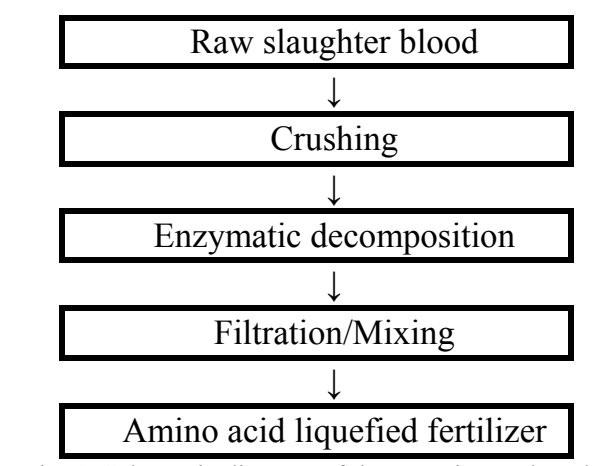

Fig. 1. Schematic diagram of the experimental study.

\section{Analysis Items and Method}

The protein concentrations before and after the enzymatic reaction were measured to investigate the degree of protein decomposition in the slaughter blood. The supernatant was separated and extracted by performing centrifugation for 20 minutes at 13,000 rpm, which was then used to measure the 
protein concentration. Analysis was performed through the 'Bradford method' using bovine serum albumin (BSA: Sigma, Germany) as the standard, where the protein concentration is quantified at $595 \mathrm{~nm}$ after adding the Bradford reagent and staining with an ammonia group.

In order to determine whether the proteins were actually converted to amino acids, free amino acids and the pattern of peptides were analyzed. Analysis was performed on free amino acids using HPLC (Zorbax Eclipse-AAA Columns, Agilent, USA) after precipitating the proteins by adding TCA to the centrifuged supernatant. The peptide pattern was analyzed using gel filtration chromatography (GFC), where the pattern is determined based on the differences among the filtering speeds of various-sized samples.

The particle size was measured using the laser particle size analyzer (780 AccuSizer, USA) with a measurement range of $0.5 \sim 500 \mu \mathrm{m}$. In addition to the above items, 3-components, ultimate analysis, heavy metals, $\mathrm{pH}, \mathrm{C} / \mathrm{N}$ ratio and salinity were measured.

\section{RESULTS AND DISCUSSION}

\section{A. Determination of the Optimum Conditions of the Enzymatic Decomposition Reaction}

The operation conditions were varied to determine the optimum conditions of the enzymatic decomposition reaction, and results of the protein concentrations measured before and after the treatments are shown in Fig. 2. The changes of the protein concentration according to the reaction time under various reaction temperatures were analyzed (Fig. 2(a)). During this experiment, $1.00 \mathrm{w} / \mathrm{w} \%$ of enzyme was added for sufficient reaction.

The highest activity of protein decomposition was seen at a reaction temperature of $40^{\circ} \mathrm{C}$, while there was a decreased protein decomposition activity at $15^{\circ} \mathrm{C}$ (room temperature). Also, a decreased speed of protein decomposition was seen at a reaction temperature of $60^{\circ} \mathrm{C}$ and this is thought to be due to the inactivation of the enzyme caused by high temperature. The activity of protein decomposition was relatively high up to $4 \mathrm{hrs}$ at $60^{\circ} \mathrm{C}$, which can be explained by the fact that the actual temperature did not reach the target temperature immediately. The changes in the protein concentration in respect to the reaction time show that there were no significant changes between 4 8 hours, while there was a gradual step-by-step reduction in the protein concentration after 10 hours with minor changes occurring afterwards. Thus, the optimum reaction temperature and time were determined to be $40^{\circ} \mathrm{C}$ and $10 \mathrm{hrs}$, respectively.

The changes of the protein concentration with different enzyme mixing ratio were analyzed (Fig. 2(b)). The enzyme mixing ratio was varied in a range of $0.25,0.5,0.75$ and 1.00 $\mathrm{w} / \mathrm{w} \%$, and the protein concentration was analyzed after undergoing reaction for 10 hours at $40^{\circ} \mathrm{C}$. Addition of more than $0.5 \mathrm{w} / \mathrm{w} \%$ of enzyme did not cause any significant reduction in the protein concentration. Although a sufficient amount of enzyme need to be added for protein decomposition in slaughter blood, it is even more essential to determine the appropriate amount be used in the reaction because enzymes are extremely expensive. Thus, $0.5 \mathrm{w} / \mathrm{w} \%$ of enzyme was determined to be the optimum enzyme mixing ratio.

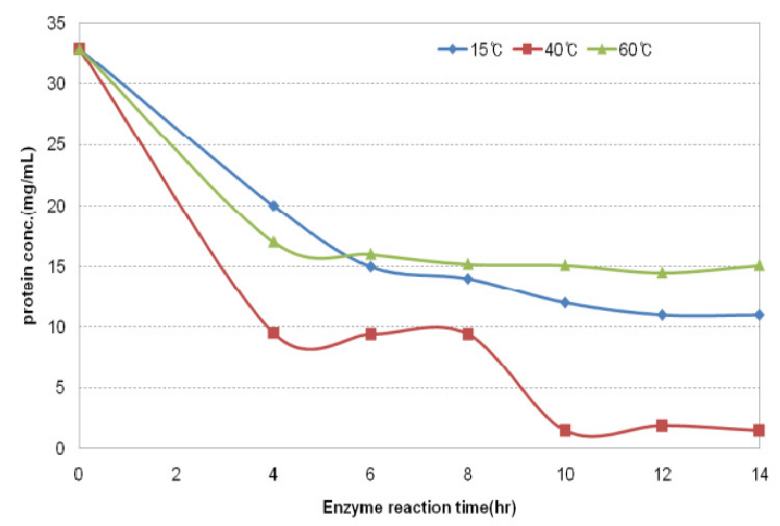

(a)

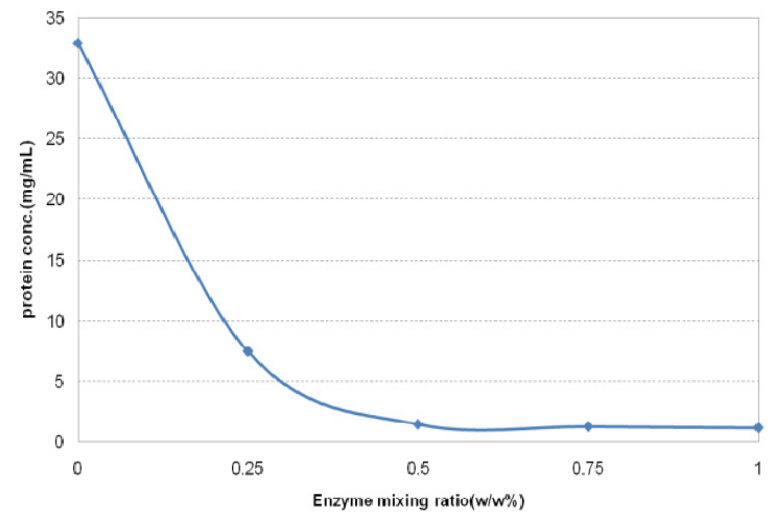

(b)

Fig. 2. Measurement of the protein concentrations in various reaction conditions (a) changes of the protein concentrations according to the reaction time under various reaction temperatures, (b) changes of the protein concentration with different enzyme mixing ratio (reaction time: $10 \mathrm{hrs}$ )

\section{B. Enzymatic Decomposition of Slaughter Blood at Optimum Operation Conditions}

The optimum reaction conditions to maximize the efficiency of enzymatic decomposition for raw slaughter blood are as follows: enzyme mixing ratio of $0.5 \mathrm{w} / \mathrm{w} \%$, reaction temperature of $40^{\circ} \mathrm{C}$ and reaction time of $10 \mathrm{hrs}$. The results of the enzymatic decomposition of slaughter blood at the optimum reaction conditions are shown in Table III. The protein concentration, which is the primary index used to determine the degree of blood protein decomposition by enzyme, decreased by more than $95 \%$ from $32.9 \mathrm{mg} / \mathrm{mL}$ before treatment to $1.5 \mathrm{mg} / \mathrm{mL}$ after treatment. However, these results do not represent the amount of proteins converted into amino acids.

An analysis was performed on the particle size distributions before and after the crushing and enzymatic decomposition processes. The particles were found to have decreased in size; the average diameter of the particles in the raw slaughter blood prior to treatment was found to be 46.92 $\mu \mathrm{m}$, whereas the average diameter after the crushing and enzymatic decomposition processes was determined to be $19.89 \mu \mathrm{m}$. Considering that average size of microorganisms is measured in $\mu \mathrm{m}$, the decrease in the average particle size is thought to have been caused by not only protein 
decomposition due to enzymatic reaction but also destruction of large solid materials in the raw slaughter blood. The enzyme acts on a specific sites exposed on the surface of proteins. Because of that, particles with the larger diameter have a low enzymatic decomposition rate compared to smaller particles, which can play a role in causing limitations in the overall enzymatic decomposition reaction. Effective crushing of blood promotes enzymatic decomposition reactions and thus, it is expected to have a significant impact on the efficiency of conversion of slaughter blood into amino acid liquefied fertilizer.

TABLE III: EFFECTS OF ENZYMATIC DECOMPOSITION OF SLAUGHTER BLOOD UNDER THE OPTIMUM REACTION CONDITIONS OBTAINED FROM PREVIOUS EXPERIMENTS

\begin{tabular}{|c|c|c|c|c|}
\hline \multicolumn{2}{|r|}{ Items } & Unit & Untreated & Treated \\
\hline \multicolumn{2}{|r|}{$\mathrm{pH}$} & - & 6.51 & 6.84 \\
\hline \multicolumn{2}{|c|}{$\mathrm{C} / \mathrm{N}$ ratio } & - & 6.21 & 7.07 \\
\hline \multicolumn{2}{|c|}{ Salinity } & $\%$ & 0.46 & 0.49 \\
\hline \multicolumn{2}{|r|}{ Protein } & $\mathrm{mg} / \mathrm{L}$ & 32.9 & 1.5 \\
\hline \multicolumn{2}{|c|}{ Average particle size } & $\mu l$ & 46.92 & 19.89 \\
\hline \multirow{16}{*}{$\begin{array}{l}\text { Amino } \\
\text { acid }\end{array}$} & Aspartate & $\mathrm{pmol} / \mu \mathrm{l}$ & N.D. & 145.3 \\
\hline & Glutamate & $\mathrm{pmol} / \mu \mathrm{l}$ & 58.8 & 260.8 \\
\hline & Serine & $\mathrm{pmol} / \mu \mathrm{l}$ & N.D. & 647.3 \\
\hline & Histidine & $\mathrm{pmol} / \mu \mathrm{l}$ & N.D. & 570.3 \\
\hline & Glycine & $\mathrm{pmol} / \mu \mathrm{l}$ & 126.4 & 188.3 \\
\hline & Threonine & $\mathrm{pmol} / \mu \mathrm{l}$ & N.D. & 706.9 \\
\hline & Alanine & $\mathrm{pmol} / \mu \mathrm{l}$ & 61.6 & $1,909.6$ \\
\hline & Tyrosine & $\mathrm{pmol} / \mu \mathrm{l}$ & 8.7 & 636.4 \\
\hline & Valine & $\mathrm{pmol} / \mu \mathrm{l}$ & 26.1 & $1,698.1$ \\
\hline & Methionine & $\mathrm{pmol} / \mu \mathrm{l}$ & N.D. & 599.3 \\
\hline & Phenylalanine & $\mathrm{pmol} / \mu \mathrm{l}$ & 12.7 & $2,889.3$ \\
\hline & Leucine & $\mathrm{pmol} / \mu \mathrm{l}$ & 15.2 & $3,463.6$ \\
\hline & Proline & $\mathrm{pmol} / \mu \mathrm{l}$ & 12.8 & 43.5 \\
\hline & Isoleucine & $\mathrm{pmol} / \mu \mathrm{l}$ & 6.3 & N.D. \\
\hline & Lysine & $\mathrm{pmol} / \mu \mathrm{l}$ & 11.1 & N.D. \\
\hline & Sum & $\mathrm{pmol} / \mu \mathrm{l}$ & 339.5 & $13,758.7$ \\
\hline
\end{tabular}

Note) N.D.: not detectable

\section{Analysis of Free Amino Acids}

Small-sized polypeptides, peptides and amino acids cannot be quantified through the 'Bradford method'. That is, whether the decreased proteins were converted into amino acids cannot be confirmed accurately through the measurement of the protein concentration using the 'Bradford method'. Thus, an analysis was performed on free amino acids before and after treatment in optimum conditions using HPLC in order to determine whether the decreased proteins were converted into amino acids and the results are shown in Table III.

After the enzymatic decomposition treatment, the concentration of free amino acids increased 40-fold from $339.5 \mathrm{pmol} / \mu \mathrm{l}$ to $13,758.7 \mathrm{pmol} / \mu \mathrm{l}$. However, considering that the total protein content prior to treatment was 32.9 $\mathrm{mg} / \mathrm{mL}$, it is believed that only some of the proteins were converted to amino acids during the process in which the proteins of the raw slaughter blood were decomposed into proteins and peptides of various sizes.

\section{Analysis of the Peptide Pattern}

The peptide pattern was analyzed using GFC and the results are shown in Fig. 3. GFC was conducted with following standard samples: BSA (66 kDa), Carbonic anhydrase (29 kDa), RNase A (13.7 kDa) and Aprotinin (6.5 $\mathrm{kDa}$ ). These peaks were used as size markers for comparison to the actual data (Fig. 3(a)).
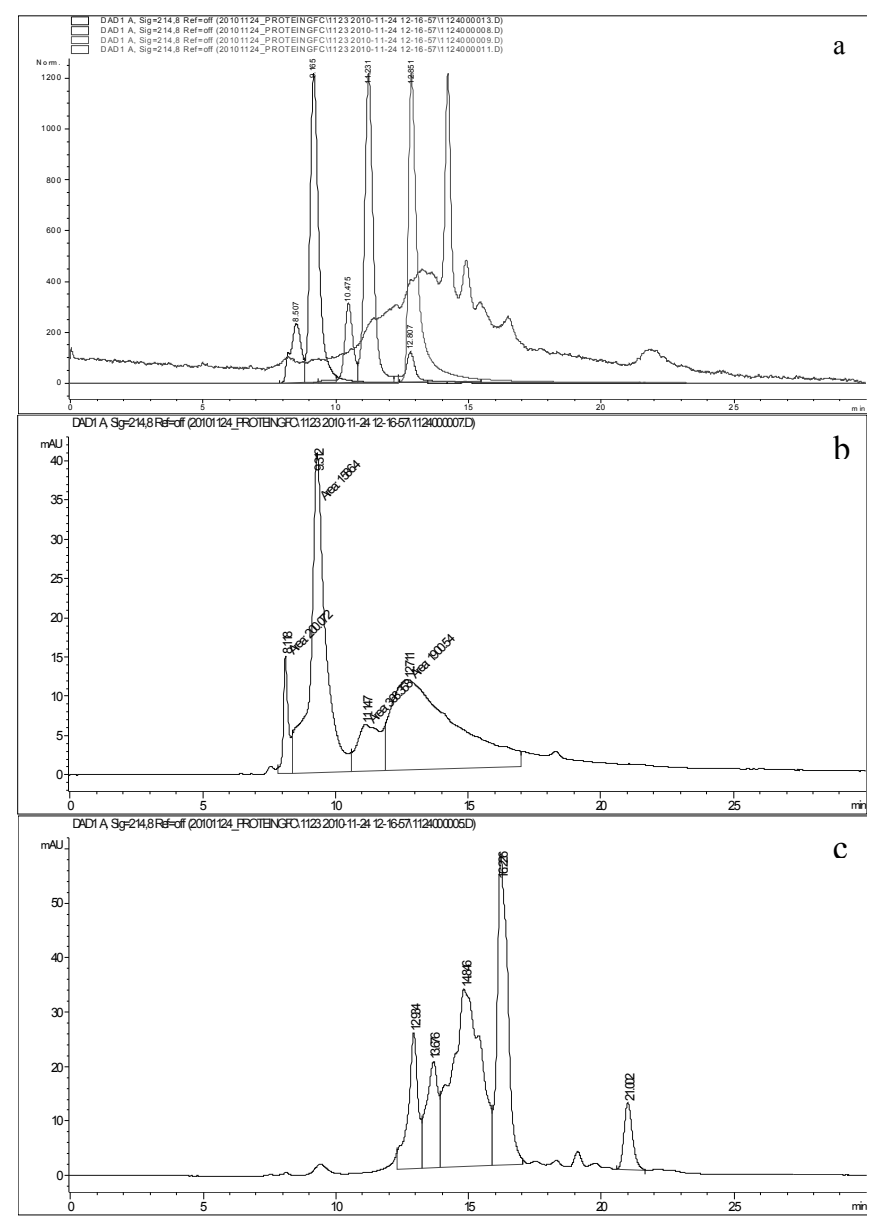

Fig. 3. Result of the GFC analysis (a) standard samples: BSA (66kDa, first peak), Carbonic anhydrase (29kKa, second peak), RNase A (13.7kDa, third peak), and Aprotinin (6.5kDa, fourth peak), (b) sample before treatment (raw slaughter blood), (c) sample after treatment under optimum reaction conditions

The results of the peptide analysis before (Fig. 3(b)) and after (Fig. 3(c)) the enzymatic decomposition process show that several peaks seen before the treatment generally moved to the right side of the graph after the treatment. Also, pattern of peaks after the treatment changed more complex. This signifies that the proteins with bigger molecular weight have been degraded into several particles of smaller sizes through enzymatic decomposition. The raw slaughter blood sample has a peak located left or corresponding to the peak of the BSA sample $(66 \mathrm{kDa})$, which represents proteins that are over $66 \mathrm{kDa}$ in mass. Samples after the treatment were represented as several peaks locating in the range between the peak of RNase A ( $13.7 \mathrm{kDa})$ and the far right of Aprotinin $(6.5 \mathrm{kDa})$. These peaks represent small proteins and peptides. This means that the decomposed proteins were converted to smaller proteins and peptides of less than $13 \mathrm{kDa}$ in mass, and were not converted into amino acid level. 


\section{CONCLUSION}

This study attempted to produce amino acid liquefied fertilizer from slaughter blood through crushing and enzymatic decomposition processes.

The conclusions made from this research are as follows:

1) To maximize the efficiency of enzymatic decomposition for raw slaughter blood, the optimum operation conditions are determined as follows: a) Enzyme reaction time is $10 \mathrm{hrs}$, b) Enzyme mixing ratio is $0.5 \mathrm{w} / \mathrm{w} \%$, c) Enzyme reaction temperature is $40^{\circ} \mathrm{C}$.

2) Decomposed blood by crushing and enzymatic reaction showed decrease of total protein concentration from 32.9 $\mathrm{mg} / \mathrm{mL}$ to $1.5 \mathrm{mg} / \mathrm{mL}$, and average particle size from 46.92 $\mu \mathrm{m}$ to $19.89 \mu \mathrm{m}$.

3) After the enzymatic decomposition treatment, the concentration of free amino acids increased 40-fold from $339.5 \mathrm{pmol} / \mu \mathrm{l}$ to $13,758.7 \mathrm{pmol} / \mu \mathrm{l}$. However, considering that the total protein content prior to treatment was 32.9 $\mathrm{mg} / \mathrm{mL}$, it is believed that only some of the proteins were converted to amino acids during the process in which the proteins of the raw slaughter blood were decomposed into proteins and peptides of various sizes.

4) Through GFC analysis, decomposed proteins were converted mostly into small-sized protein and peptide $(<13$ $\mathrm{kDa}$ ) not into amino acid level.

Production of amino acid liquefied fertilizer from slaughter blood through enzymatic biodegradation requires development and application of appropriate proteases and finer blood crushing technology, and additional researches concerning these matters are deemed necessary.

\section{ACKNOWLEDGMENT}

This research was supported by "Korea Institute of Planning and Evaluation for Technology in Food, Agriculture, Forestry and Fisheries (IPET)" (project
112040-3).

\section{REFERENCES}

[1] Ministry of Food, Agriculture, Forestry and Fisheries. (Republic of Korea). (2011). Fertilizer Legal Standards - Public Notification of MIFAFF in Korea. [Online]. Available: http://www.mifaff.go.kr.

[2] Y. Jang, H. Kim, M. Lee, H. Baek, and N. Choe, "Utilization and hygiene status of animal blood from slaughterhouse in Korea," Kor. $J$. Vet. Publ. Hlth, vol. 35, no. 2, pp. 73-79, 2011.

[3] Chang-Kee Hyun and Heuyn-Kil Shin, "Production of angiotensin I converting enzyme inhibitory peptides from bovine blood plasma proteins," Korean J. Biotechnol, Bioeng, vol. 14, no. 5, pp. 600-605, 1999.

[4] M. Jeoung-Suk, S. Kwan-Seob, and P. Garng-Hee, "Utilization of porcine blood and liver in yeast culture for animal diets and effects of yeast culture on the growth of broiler chicks," Journal of Livestock Housing and Environment, pp. 21-28, 2001.

[5] Ministry of Agriculture and Forestry, "Reutilization of Porcine Blood Collected after Slaughter as Animal Feeds," 1995.

[6] Ministry of Agriculture and Forestry, "Utilization of animal blood produced from slaughterhouse," 1998.

[7] H. W. Ockerman and C. L. Hansen, "Animal by-product processing," Ellis Horwood Ltd., Chichester, England, pp. 239-265, 1994.

[8] Y. S. Kim, K. S. Lee, and S. G. Ham, "The effect of liquid fertilizer contained amino acids on the growth of Bentgrass(Agrostis palustris Huds) and the chemical characteristics of soil," Korea Turfgrass Science, vol. 17, no. 4, pp. 147-154, 2003.

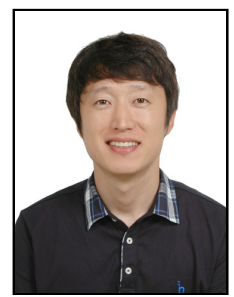

Y. W. Jeon is a Ph. D. in the Department of Energy and Environmental System Engineering, The University of Seoul, Seoul, Korea, March 2011 to present (Ongoing). He was in the M. S. Department of Environmental Engineering, Ajou University, Suwon, Korea during March 2002 February 2004. And he was in the B. S. Department of Environmental Engineering, Ajou University, Suwon, Korea during March 1996 February 2002.

$\mathrm{He}$ was an engineer at Yooshin Engineering Corporation during February $2004 \sim$ October 2006, a researcher at Pohang University of Science and Technology during May 2007 August 2007. He is the senior researcher at Korea Testing Laboratory (KTL) from October 2007 to present. 